\title{
SARS-CoV-2 precipitated Kasabach-Merritt syndrome in a child with angioma infantile and acute lymphoblastic leukemia: Case Report
}

\section{Sindrome de Kasabach-Merritt precipitado por SARS-CoV-2 en un niño con angioma infantil y leucemia linfoblástica aguda: Reporte de Caso}

\begin{abstract}
Background: We describe an 8-month-old boy with leukemia and SARS-CoV-2 infection who developed Kasabach-Merritt phenomenon. He had a positive SARSCOV-2 RT-PCR sample. Hematologic tests showed coagulopathy and intestinal involvement. She was managed in emergency receiving transfusion support and in hospitalization with social isolation measures, she started propanolol and corticotherapy as initial treatment of infantile angiomas. She presented with symptoms of intestinal obstruction and underwent surgery and evidence of hemorrhagic infarction with foci of intestinal ischemic necrosis, ending in ileostomy. We tried to understand a pathophysiological explanation of the dermatologic and gastrointestinal tract involvement by the virus and the atypical form of COVID-19. Given the emerging evidence of endothelial and vascular involvement in COVID-19, the development of tests to detect vascular lesions may be critical to guide the use of new therapeutic strategies.
\end{abstract}

Keywords: Kasabach-Merritt Syndrom; Child; Pediatrics; SARS-CoV-2 (Source: DeCS-BIREME).

\section{RESUMEN}

Introducción: Describimos a un niño de 8 meses con leucemia e infección por SARS-CoV-2 que desarrolló el fenómeno de Kasabach-Merritt. Tenía una muestra de RT-PCR de SARS-COV-2 positiva. Las pruebas hematológicas mostraron coagulopatía y afectación intestinal. Fue manejada en emergencia recibiendo apoyo transfusional y en hospitalización con medidas de aislamiento social, inició propanolol y corticoterapia como tratamiento inicial de los angiomas infantiles. Presentó síntomas de obstrucción intestinal y fue intervenida quirúrgicamente y se evidenció infarto hemorrágico con focos de necrosis isquémica intestinal, terminando en ileostomía. Intentamos comprender una explicación fisiopatológica de la afectación dermatológica y del tracto gastrointestinal por el virus y la forma atípica de

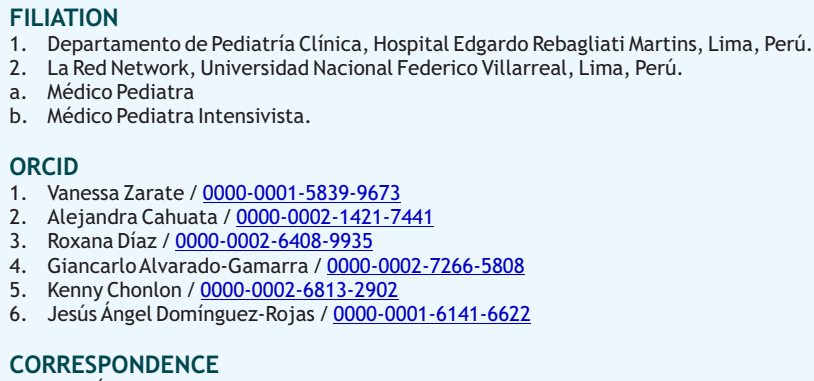

Dr. Jesús Ángel Domínguez Rojas, Departamento de Pediatría, Hospital Edgardo Rebagliati Martins, Fray Angélico 238 Dpto 103, San Borja, Lima, Perú, Tel.: +51953907559

EMAIL

jesusdominguez24@gmail.com

CONFLICTS OF INTEREST

The authors of this manuscript certify that they have no affiliations with or involvement in any organization or entity with any financial interest (such as honoraria; educational grants; participation in speakers' bureaus; membership, employment, consultancies, stock ownership, or other equity interest; and expert testimony or patent-licensing arrangements) or nonfinancial interest (such as personal or professional relationships, affiliations, knowledge or beliefs) in the interest (such as personal or professional relationships,
subject matter or materials discussed in this manuscript.

FINANCING

Self-financin.

\section{AUTHOR CONTRIBUTIONS}

All persons who meet authorship criteria are listed as authors, and all authors certify that they have participated sufficiently in the work to take public responsibility for the content, including participation in the concept, design, analysis, writing, or revision of the manuscript.

\section{CONSENTTO PARTICIPATE}

The authors of this manuscript certify that informed consent was obtained and signed from the patient's parent/legal guardian to participate in this case report for submission to the journal.

\section{CONSENT TO PUBLISH}

The authors of this manuscript certify that informed consent was obtained and signed from the participant's parent/legal guardian regarding publishing their data and photographs.

\section{PEER REVIEW}

Received: 06/09/2021

Accepted: $10 / 10 / 2021$

\section{HOW TO CITE}

Zarate, V., Cahuata, A., Díaz, R., Alvarado-Gamarra, G., Chonlon, K., \& Domínguez-Rojas, J. Sindrome de Kasabach-Merritt precipitado por SARS-CoV-2 en un niño con angioma infantil y leucemia linfoblástica aguda: Reporte de Caso. Revista Del Cuerpo Médico Hospital Nacional A I m a n zor A guinaga As e n jo, $2021,14(3), 387$ - 389 . https://doi.org/10.35434/rcmhnaaa.2021.143.1278

(i)

This work is under a Licencia Creative Commons Atribución 4.0 Internacional.

Printer Version: ISSN: 2225-5109

Electronic Version: ISSN: 2227-4731

Cross Ref. DOI: $10.35434 /$ rcmhnaaa

OJS: https://cmhnaaa.org.pe/ojs 
COVID-19. Dada la evidencia emergente de la afectación endotelial y vascular en COVID-19, el desarrollo de pruebas para detectar lesiones vasculares puede ser crítico para guiar el uso de nuevas estrategias terapéuticas.

Palabras Clave: Síndrome de Kasabach-Merritt; Niño; Pediatría; SARS-CoV-2 (Fuente: DeCS-BIREME).

\section{INTRODUCTION}

The association between giant hemangioma and thrombocytopenia was described by Haig Kasabach and Katharine Merritt in $1940^{(1)}$. Kasabach Merritt syndrome is usually a rapidly growing vascular anomaly causing consuming coagulopathy, thrombocytopenia, hypofibrinogenemia, Dimero d high, microangiopathic hemolytic anemia, prolonged prothrombin time and partial thromboplastin time; this syndrome is $90 \%$ associated with Kaposiform Hemangioendothelioma ${ }^{(2,3)}$. KHE has an unpredictable course and with visceral infiltration are considered extensive and unresectable lesions, so they have a poor prognosis ${ }^{(4)}$.

\section{CASE PRESENTATION}

An 8-month-old boy with debut of acute lymphoblastic leukemia and angioma infantile who presented with Kasabach Merritt syndrome precipitated by SARS-CoV-2 infection. According to the mother, 5 days ago he presented fever, rhinorrhea and describes a violaceous lesion in the right dorsal region. RNA testing for SARS coronavirus 2 was performed on a respiratory specimen by RT-PCR and was positive. A $6 \times 7 \mathrm{~cm}$ diameter, indurated, purplish-red lesion with superficial telangiectasias was observed [Figure 1]. Thoracic angiography showed vascular pedicle in the dorsal trajectory related to vascular structures branches of the intercostal 11 and 12 without organ involvement [Figure 2]. Blood tests on the fifth day show severe thrombocytopenia $7000 / \mathrm{mm} 3$ (150000- 400000/mm3), leukopenia $1740 / \mathrm{mm} 3$ $(5000-14500 / \mathrm{mm} 3)$, and severe neutropenia $130 / \mathrm{mm} 3$ $(1800-8000 / \mathrm{mm} 3)$, positive C-reactive protein $24.9 \mathrm{mg} / \mathrm{dl}(0$ $1 \mathrm{mg} / \mathrm{dl})$ and hypoalbuminemia $2.89 \mathrm{~g} / \mathrm{dl}(3,2-4,8 \mathrm{~g} / \mathrm{dl})$, elevated prothrombin time $103.48 \mathrm{sec}(10,5-17 \mathrm{sec})$, INR 11. 45, d-dimer $15.4 \mathrm{ug} / \mathrm{ml}(0-0,54 \mathrm{ug} / \mathrm{ml})$, partial thromboplastin time and undetectable fibrinogen (200-400 $\mathrm{mg} / \mathrm{dl})$, ferritin $561.3 \mathrm{ng} / \mathrm{ml}(28-365 \mathrm{ng} / \mathrm{ml})$, receiving platelet transfusions, cryoprecipitate, propanolol and methylprednisolone. Prior to the start of treatment with propranolol, a cardiological evaluation was performed. Propranolol was used according to the initial management of infantile angiomas, and corticosteroids in case of suspected kaposiform hemangioma, with transient improvement. After two weeks of hospitalization he presented vomiting, abdominal distension, painful abdomen on palpation, with suspicion of intestinal obstruction and underwent surgery, presenting abdominal perforation and ending with functional ileostomy. The biopsy of the intestinal segment described hemorrhagic infarction lesions with foci of ischemic necrosis, without evidence of thrombi.

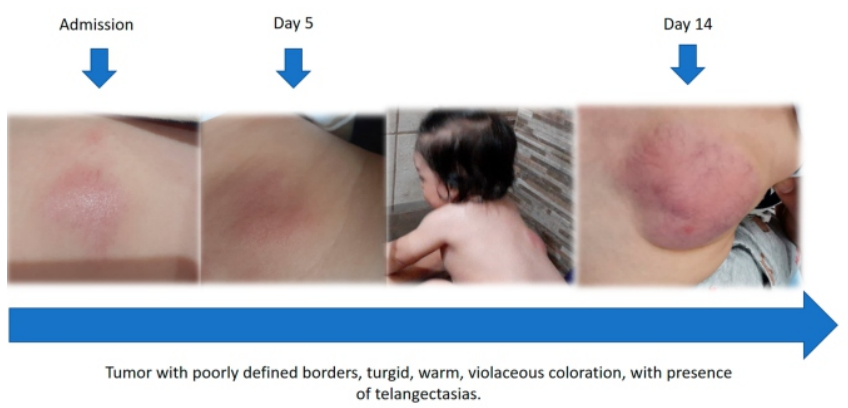

Figure 1.

Evolving dermatological images of the vascular lesion

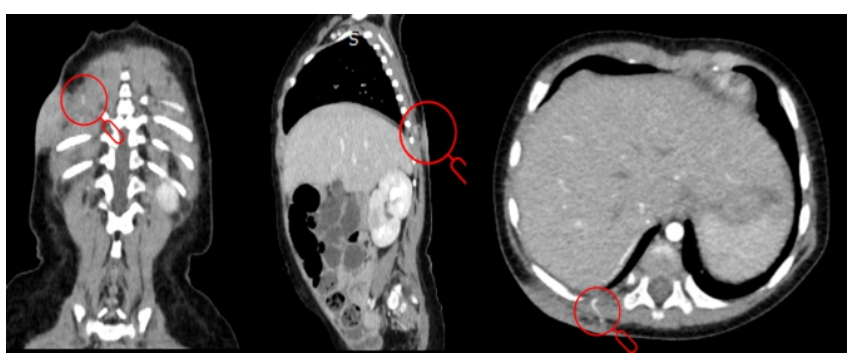

Figure 2.

Thoracic Tomography

The images describe a soft tissue lesion in the lower right posterolateral thoracic wall measuring $11 \mathrm{~mm}$ thick and 5.9 $\mathrm{cm}$ in greatest diameter, related to vascular structures of the intercostal branches 11 and 12 on the same side, best represented in arterial phase.

\section{DISCUSSION}

The wide range of underlying causes and mechanisms of cutaneous involvement in viral infections justifies that SARSCoV-2 infection may trigger cutaneous or vascular alterations.

The mechanisms of vascular injury in COVID-19 appear to be related to inflammation, endothelial injury and thrombosis ${ }^{(5)}$. Above all, increased immune responses and cytokine storms cause thrombotic disorders in patients with severe COVID-19, with high levels of $d$-dimer being found in most patients with COVID-19 $19^{(6,7)}$.

SARS-CoV-2 infection may be a precipitating factor of Kasabach-Merritt phenomenon and intestinal coagulopathies. 
It should be reported that the observed vascular cutaneous manifestations, should also pay attention in predicting the prognosis of patients with COVID - 19 [8]. Treatment of KM is supportive and prevention of life-threatening complications while addressing the underlying tumor ${ }^{(9)}$. This condition caused by COVID-19 focuses on gastrointestinal decompression, fluid resuscitation, hemodynamic support, surgical resection of necrotic bowel, and restoration of blood flow to the ischemic bowel ${ }^{(10)}$.

\section{CONCLUSIONS}

SARS-CoV-2 in children with cancer can precipitate the formation of giant vascular lesions with Kasabach-Merritt phenomenon. Coagulopathy caused by SARS-CoV-2 exposure requires evaluation of all organs at risk for thrombosis. SARSCoV-2 in children with comorbidities may pose a critical risk, including admission to a pediatric intensive care unit.

\section{BIBLIOGRAPHIC REFERENCES}

1. HH K, KKM. Capillary hemangioma with extensive purpura: Report of a case. Am J Dis Child. 1940 May 1;59(5):1063-70.

2. Wang $\mathrm{P}$, Zhou W, Tao L, Zhao N, Chen X-W. Clinical analysis of kasabach-merritt syndrome in 17 neonates. BMC Pediatr. 2014 Jun
$11 ; 14: 146$.

3. Acharya S, Pillai K, Francis A, Criton S, Parvathi VK. Kasabach merritt syndrome: management with interferon. Indian J Dermatol. 2010;55(3):281-3.

4. Drolet BA, Trenor CC, Brandão LR, Chiu YE, Chun RH, Dasgupta R, et al. Consensus-derived practice standards plan for complicated Kaposiform hemangioendothelioma. J Pediatr. 2013;163(1):28591.

5. Roumen - Klappe EM, den Heijer M, van Uum SH, et al. Respuesta inflamatoria en la fase aguda de la trombosis venosa profunda . J Vasc Surg. 2002; 35 ( 4 ): 701-706.

6. José RJ, Manuel A. Tormenta de citocinas COVID-19: la interacción entre la inflamación y la coagulación. Lancet Raspir Med. 2020; 8 (6): e46 - e47.

7. Zhou F, Yu T, Du R y col. Curso clínico y factores de riesgo para la mortalidad de adultos en pacientes con COVID-19 en Wuhan, China: un estudio de cohorte retrospectivo. Lancet. 2020; 395 (10229): 1054-1062.

8. Afsaneh Sadeghzadeh-Bazargan MD, Mahdi Rezai MD. Skin manifestations as potential symptoms of diffuse vascular injury in critical COVID-19 patients. J Cutan Pathol. 15 de junio de 2021: 10.1111 / cup. 14059.

9. Priya Mahajan, Judith Margolin. Kasabach-Merritt Phenomenon: Classic Presentation and Management Options. Clin Med Insights Blood Disord. 2017 Mar 16; doi:10.1177/1179545X17699849.

10. Balraj Singh, Ashesha Mechineni. Acute Intestinal Ischemia in a Patient with COVID-19 Infection. Korean J Gastroenterol 2020; 76(3): 164-166. https://doi.org/10.4166/ kjg.2020.76.3.164. 